\title{
HUBUNGAN FINANCIAL DISTRESS \& MEKANISME GCG TERHADAP PELAPORAN AUDIT PADA PERUSAHAAN PERBANKAN YANG TERDAFTAR DI BURSA EFEK INDONESIA PERIODE 2005-2010
}

\author{
Mario Pratama Putra Riyanda* \\ Susi Indriani**
}

\begin{abstract}
This study examines the relation between the composition of financially distressed banks, boards of director Committees and institusional ownership to the likelihood of receiving going concern reports. The composition board of director Committees and institusional ownership represent Good Corporate Governance (GCG) mechanism in banks. Financial firms were highly regulated, so we combine bapepam regulation and altman $Z$ score to identify banks that fit for the financial distress category. For banks experiencing financial distress during 2005-2010, by using logistic regression we find that the greater percentage of financial distress in banks, the smaller the probability the Auditor will issue a going concern report. This empirical study did not support role GCG mechanism on Audit reporting. These results can give us a little sight about implementation of GCG in Indonesia specialy for financial firm. The contribution will go to support regulators' concern about financial reporting, firms behavior (financiall and non financial firms) in making healthy environment with GCG and the need of balancing proportion in ownership structure in form of the composition board committee and institusional ownership to minimize moral hazard .
\end{abstract}

Keywords : financial distress, board of director Committees, institusional ownership and going concern reports

\section{PENDAHULUAN}

Mario Pratama Putra Riyanda adalah Dosen Fakultas Ekonomi, UPN "Veteran" Jakarta

** Susi Indriani adalah dosen Fakultas Ekonomi, Universitas Negeri Jakarta
Peran auditor independen sebagai "watchdogs" bagi para pengguna laporan keuangan dirasakan sangat crucial, penekanan makna peran tersebut terutama diamini oleh para pembuat 
kebijakan di Amerika (Levitt 1998). Pertimbangan auditor atas kelangsungan usaha penting untuk perusahaan agar dapat menjalankan aktivitasnya dalam mencapai tujuan, baik tujuan jangka pendek maupun tujuan jangka panjang. Penelitian terdahulu menunjukkan bahwa opini going concern merupakan keputusan audit tersulit dan mempunyai makna ambigu (Chow et all, 1987 ; Carmichael \& Pany , 1993). Situasi yang menempatkan auditor pada posisi ini ditenggarai sebagai suatu toleransi atas posisi klien, meski seperti dinyatakan bahwa hal ini tidak terlalu jelas terlihat namun nyata terjadi (Salterio \& Koonce, 1997). Kesulitan pengambilan keputusan pada posisi ini akan mengarah kepada independensi dari pihak auditor yang rapuh karena adanya tekanan dari pihak manajemen.

Namun dalam kenyataannya kelangsungan hidup perusahaan bukanlah hal yang mudah pada kondisi perekonomian yang selalu tidak menentu dan persaingan yang terus berkembang. Di Indonesia banyak perusahaan yang kalah bersaing dan akhirnya mengalami kebangkrutan, terutama pada sektor perbankan. Krisis moneter yang melanda beberapa negara di Asia termasuk Indonesia pada tahun 1997, membawa dampak buruk bagi kelangsungan hidup entitas bisnis termasuk bisnis perbankan (http://www.kompas.com/ di akses pada tanggal 15 oktober 2011). Dalam kurun waktu 1999 sampai September 2005 telah terjadi skandal tindak pidana perbankan sebanyak 482 kasus yang terjadi dalam 254 bank dengan tindak pidana berupa rekayasa kredit, penyalahgunaan wewenang oleh pemegang saham, direksi, komisaris dan pejabat bank, rekayasa laporan keuangan pelanggaran komitmen dan ekspor fiktif (Ari dalam Arafat \& Fajri,2009;170) . Dari banyak kasus tersebut beberapa menyita perhatian public yang cukup besar seperti Bank Lippo dan Bank Century. Pada tahun 2002 Bank Lippo mendapat opini audit wajar tanpa pengecualian namun gagal pada tahun 2003. Persoalan berawal ketika manajemen Bank Lippo mempublikasikan laporan keuangan di media massa. Terdapat perbedaan laporan keuangan Bank Lippo yang saling bertentangan ( http://berita.liputan6.com/ di akses pada tanggal 17 oktober 2011). Kasus Bank Century terungkap pada tahun 2008 yang diakibatkan oleh jatuhnya surat-surat berharga valas dan gagal bayar yang menyebabkan kesulitan likuiditas (http://bbc.co.uk/indonesial di akses tanggal 17 oktober 2011). 
Dari data laporan keuangan BEI antara rentang tahun 2005 - 2010 terdapat beberapa perusahaan perbankan yang telah delisting (tidak terdaftar) pada tahun berikutnya dan kemudian pada tahun berikutnya perusahaan perbankan tersebut kembali masuk ke dalam daftar BEI.

Dengan meningkatnya kasus perbankan di Indonesia beberapa tahun ini, maka integritas perbankan kita menjadi pertanyaan besar. Dengan data dan fakta tersebut maka peranan pemerintah sebagai pembuat kebijakan dan penegakan hukum menjadi suatu keharusan yang mesti segera dibenahi. Terutama sejak dikeluarkannya Peraturan Pemerintah tentang Deregulasi Kegiatan Perbankan yang lebih mengarah ke liberalisasi Perbankan, telah membawa dampak ke masingmasing bank. Dengan semakin tajamnya persaingan di antara bank-bank untuk merebut market share dalam rangka mempertahankan kelangsungan usahanya untuk mengembangkan usahanya masing-masing.

Seperti telah disebutkan sebelumnya bahwa pemberian status going concern bukanlah perkara yang mudah untuk diputuskan, karena seorang auditor mengalami dilema antara moral dan etika yang disebabkan self fulfilling prophecy. Venuti (2007) dalam Januarti (2009) menyatakan terdapat dampak yang nyata terhadap perusahaan yang mendapatkan status going concern dimasa yang akan datang dan mempercepat kebangkrutan perusahaan, hal ini membuat seorang auditor mengeluarkan opini wajar tanpa pengecualian yang seharusnya meragukan kelangsungan hidup entitasnya. Selain itu bila perusahaan berstatus going concern para investor akan membatalkan investasinya atau kreditor akan menarik dananya.

Sehingga sangat penting bagi perusahaan untuk menghindari status going concern bagi eksistensi kegiatan entitasnya. Hal ini menimbulkan teori keagenan dimana pihak manajemen harus membuat keputusan yang sulit sehingga harus mengintervensi laporan keuangan atas tekanan dari pihak institusional. Pihak manajemen harus terus memastikan laporan keuangan harus tetap stabil agar para investor perusahaan akan terus menyuntikkan dana segar ke dalam perusahaan.

Dengan

mengaitkan

kepentingan manajemen dalam tersebut serta fakta skandal yang mendominasi peranan "orang dalam" yang ada dalam dunia 
perbankan Indonesia belakangan ini maka dapat dikatakan hal ini merupakan indikasi buruknya pelaksanaan Good Corporate Governance (GCG) dalam dunia perbankan kita. Istilah Corporate Governance (CG) atau Good Corporate Governance (GCG) sendiri merupakan istilah yang populer sampai saat ini, baik di dunia apalagi di Indonesia yang mengacu pada transparansi dan akuntabilitas dalam pelaporan keuangan. Menurut Daniri $(2005 ; 5)$ setidaknya terdapat 3 (tiga) faktor yang melatarbelakangi popularitas tersebut. Pertama, kegagalan penerapan CG diyakini sebagai salah satu penyebab utama krisis ekonomi di kawasan Asia dan Amerika Latin. Kedua, CG semakin populer setelah terungkapnya berbagai skandal yang dilakukan oleh perusahaan publik di Amerika dan Eropa di awal tahun 2000 (seperti Enron, Worldcom, Xerox, Merck, dil). Dan terakhir adalah adanya keyakinan bahwa penerapan GCG merupakan salah satu kunci sukses perusahaan untuk tumbuh dan menguntungkan dalam jangka panjang, sekaligus memenangkan persaingan bisnis global, terutama bagi perusahaan yang telah mampu berkembang dan berbentuk perusahaan terbuka.

Tujuan dari penelitian ini adalah untuk melihat hubungan antara mekanisme GCG dan proksi model kebangkrutan (financial distress) terhadap kecenderungan keluarnya opini audit going concern khususnya pada industry perbankan di Indonesia pada masa pengamatan. Kemudian juga untuk mengkaji masalah keagenan yang timbul atas kecenderungan keluarnya opini audit going concern bagi perusahaan. Keterkaitan hubungan kontrak antara agen (manajemen) dengan pemilik (principal). Sudah merupakan tujuan dari pihak manajemen agar laporan keuangannya mendapatkan opini wajar tanpa pengecualian, sehingga pihak manajemen akan dituntut untuk menyajikan sebuah laporan keuangan yang dapat diterima oleh pihak pemilik yang tentunya untuk menghindari opini audit going concern. Hal ini yang akan menjadi dasar manajemen untuk "menekan" auditor .

$\begin{array}{ccr}\text { Penelitian ini } & \text { akan } \\ \text { menggunakan data laporan }\end{array}$ keuangan perbankan antara tahun 2005 - 2010. Kejadian yang telah terjadi pada industry perbankan Indonesia akan membuat lembagalembaga pengatur kebijakan perbankan dan instansi pemerintah memutakhirkan dan mengevaluasi kembali kebijakan-kebijakannya. Penelitian ini merupakan pengembangan dari penelitian- 
penelitian terdahulu yang dilakukan oleh Setyarno, dkk (2006), Santosa dan Wedari (2007) dan Januarti (2009) dengan fokus pada industry perbankan yang merupakan salah satu penyangga perekonomian di Indonesia.

\section{TINJAUAN PUSTAKA}

Teori agensi merupakan salah satu aliran riset akuntansi terpenting dewasa ini. Jensen dan Meckling (1976) menggambarkan adanya hubungan kontrak antara agen (manajemen) dengan pemilik (principal). Agen diberi wewenang oleh pemilik untuk melakukan operasional perusahaan, sehingga agen lebih banyak mempunyai informasi dibandingkan pemilik. Baik pemilik maupun agen diasumsikan mempunyai rasionalisasi ekonomi dan semata-mata mementingkan kepentingannya sendiri. Asumsi lainnya menyebutkan bahwa entitas merupakan tempat atau titik pertemuan dari berbagai jenis hubungan kontraktual yang terjadi di antara manajemen, pemilik, kreditor, dan pemerintah. Agen mungkin akan takut mengungkapkan informasi yang tidak diharapkan oleh pemilik, sehingga terdapat kecenderungan untuk memanipulasi laporan keuangan tersebut.
Tujuan dari pihak manajemen dapat berbeda dari tujuan pemegang saham. Di dalam perusahaan besar, saham dapat dimiliki oleh terlalu banyak pemegang saham sehingga mereka bahkan tidak dapat mengungkapkan tujuan mereka, dan karenanya mereka hanya memiliki sedikit kendali atau pengaruh atas pihak manajemen. Jadi, pemisahan kepemilikan dari manajemen ini, akan menciptakan situasi yang memungkinkan manajer bertindak untuk kepentingan sendiri daripada untuk kepentingan pemegang saham (Horne dan Wachowicz, 2005 : 6).

Adanya asimetri informasi juga memberikan kontribusi bagi para pemegang informasi yang lebih baik, dalam hal ini adalah pihak dalam perusahaan untuk melakukan moral Hazard kepada pihak lain yang mempunyai informasi lebih sedikit. Berdasar motif teori keagenan dan adanya asimetri informasi maka akan muncul konflik antara manajemen, pemegang saham dan kreditur atau para pihak yang berkepentingan terhadap perusahaan. Manajer dapat melakukan berbagai tindakan yang menguntungkan dirinya sendiri namun disisi lain merugikan pemilik perusahaan. Yang mempunyai resiko paling besar adalah para 
pemegang saham (pemilik perusahaan), bagi para pemberi utang dengan adanya kontrak yang mengikat maka posisinya relative lebih aman. Hal ini dapat diminimalisir dengan adanya pemilikan saham oleh manajemen, sehingga tindakan manajer akan lebih sesuai dengan kepentingan para pemilik saham. Dengan adanya kepemilikan saham oleh manajemen ataupun proporsi dewan komisaris yang independent, serta adanya kontrak yang jelas pada semua pihak yang berkepentingan terhadap perusahaan maka akan menjadi control internal dan merupakan praktek pelaksanaan Corporate Governance di perusahaan.

\section{Opini Audit Going Concern}

Perusahaan diharapkan akan terus melakukan kegiatan operasinya untuk periode waktu yang tidak tertentu. Asumsinya berarti perusahaan dianggap akan mampu mempertahankan kegiatan usahanya dalam jangka waktu panjang dan tidak di likuidasi. Auditor bertanggung jawab untuk mengevaluasi kemampuan entitas kemudian menuangkannya ke dalam laporan opini audit (SAS No. 59 paragraf 2). Ini berarti bahwa perusahaan yang menyajikan laporan keuangan dianggap akan aman dalam waktu tidak terbatas. Ketika auditor menyimpulkan bahwa terdapat ketidakpastian akan kelangsungan hidup perusahaan, maka suatu laporan audit wajar tanpa syarat dengan suatu paragraf penjelasan harus diterbitkan, tanpa memperhatikan pengungkapan dalam laporan keuangan (Arens, dkk. 2003: 74).

Menurut PSA No. 30 SA Seksi 341.3 pargraf 06 menyatakan masalah going concern, yaitu masalah keuangan yang meliputi defisiensi likuiditas, defisiensi ekuitas, penunggakan utang, kesulitan memperoleh dana, serta masalah operasi yang meliputi kerugian operasi yang terusmenerus, prospek pendapatan meragukan, kemampuan operasi terancam, dan pengendalian yang lemah atas operasi.

\section{Financial Distress}

Kondisi kesehatan keuangan perusahaan yang diaudit mempengaruhi dalam proses pernyataan opini auditor. Auditor harus mempertimbangkan masalah kesangsian terhadap kelangsungan hidup perusahaan selain memperhatikan kesesuaian penyajian laporan keuangan berdasarkan prinsip-prinsip akuntansi yang berterima umum. Financial distress merupakan fase 
penurunan kondisi keuangan suatu perusahaan sebelum terjadinya kebangkrutan ataupun likuidasi. Merupakan suatu kondisi perusahaan secara menyeluruh dimana arus kas operasi tidak mampu menutupi atau mencukupi kewajiban saat jatuh tempo. Informasi financial distress ini dapat dijadikan sebagai peringatan dini atas kebangkrutan sehingga menajemen dapat melakukan tindakan secara cepat untuk menghindari masalah sebelum terjadinya kebangkrutan.

Pengaruh kondisi keuangan terhadap penerimaan opini audit going concern telah diteliti oleh Setyarno, dkk (2006). Hasil penelitian menunjukkan bahwa kondisi keuangan perusahaan berpengaruh negatif terhadap kemungkinan penerimaan opini audit going concern. Hal ini menyatakan bahwa auditor hampir tidak pernah mengeluarkan opini audit going concern pada perusahaan yang tidak mengalami kesulitan keuangan (financial distress).

Santosa dan Wedari (2007) menggunakan empat proksi dalam pengukuran kondisi keuangan perusahaan. Hasilnya ketika menggunakan proksi Altman model dan Springate model menunjukkan bahwa kondisi keuangan berpengaruh negatif terhadap kemungkinan penerimaan opini audit going concern. Ketika menggunakan proksi The Zmijeski Model dan Revised Altman Model menunjukkan bahwa kondisi keuangan tidak berpengaruh terhadap penerimaan opini audit going concern. Hal ini menyatakan bahwa semakin baik kondisi keuangan perusahaan maka semakin kecil kemungkinan bagi auditor untuk memberikan opini audit going concern, karena opini akan diberikan bila perusahaan telah sulit untuk melanjutkan kelangsungan usahanya.

Januarti (2009) menunjukkan bahwa kondisi keuangan berpengaruh signifikan negatif. Hal ini di indikasikan perusahaan yang telah sedang mengalami financial distress justru tidak menerima opini audit going concern. Hal tersebut bisa dikarenakan kurangnya independensi auditor terkait ketakutan auditor atas hal yang dapat memperburuk keadaan perusahaan. Berdasarkan teori dan penelitian sebelumnya maka dapat diasumsikan bahwa financial distress mempunyai pengaruh terhadap opini audit going concern, maka semakin tinggi kondisis financial distress suatu perusahaan akan memperkecil kemungkinan auditor mengeluarkan audit going 
concern. Maka disusun hipotesis penelitian sebagai berikut:

\section{$\mathrm{H}_{1}$ : Financial distress $\left(\mathrm{X}_{1}\right)$ suatu perusahaan mempengaruhi Auditor dalam mengeluarkan opini audit going concern ( $\mathrm{Y}$ ).}

Di dalam kepemilikan perusahaan terdapat hubungan kontrak antara agen (manajemen) dengan pemilik (Institusional). Baik pemilik maupun agen diasumsikan mempunyai rasionalisasi ekonomi dan semata-mata mementingkan kepentingannya masing-masing. Terlalu banyak pemegang saham dalam suatu perusahaan besar dikarenakan saham yang tersebar, menyebabkan mereka sulit untuk mengungkapkan tujuan dan memiliki kendali untuk mempengaruhi manajemen perusahaan. Walaupun demikian, dewasa ini semakin banyak saham yang dibeli investor institusional. karena mereka mengontrol berbagai sumber daya, maka investor itu dapat membeli dalam jumlah yang besar. Dengan proporsi kepemilikan yang baik dalam perusahaan diharapkan akan adanya efisiensi dalam kegiatan operasional perusahaan sehingga dapat memprediksi kebangkrutan perusahaan dan menghindari opini audit going concern.
Jensen dan Meckling (1976)

menyatakan kepemilikan institusional berpengaruh signifikan terhadap peningkatan nilai perusahaan, sehingga mengurangi risiko terjadinya kesulitan keuangan. Tingginya tingkat proporsi kepemilikan institusional di nilai dapat mengefisienkan penggunaan aktiva dalam perusahaan. Meningkatnya nilai perusahaan berarti akan menjauhkan perusahaan mengalami kebangkrutan sehingga dapat menghindari opini audit going concern.

Margaritis dan Psillaki (2008) menyatakan kepemilikan institusional mengarah pada kinerja perusahaan yang lebih baik dengan menurunkan biaya agen (manajemen). Dengan proporsi tingkat kepemilikan institusional yang ideal diharapkan akan adanya pengawasan keputusan manajemen, sehingga dapat mengefisienkan biaya-biaya perusahaan yang tidak terlalu dibutuhkan perusahaan. Pencegahan dan pengawasan dalam kebangkrutan akan berdampak terhadap tidak dicantumkannya opini audit going concern.

Januarti (2009) menyatakan kepemilikan institusional tidak mempengaruhi terhadap penerimaan opini audit going concern. Menurutnya fungsi kontrol 
dan pengawasan yang ada belum menjamin tidak dicantumkannya opini audit going concern.

Berdasarkan teori dan penelitian sebelumnya maka dapat diasumsikan bahwa kepemilikan institusional mempunyai pengaruh terhadap opini audit going concern, yaitu semakin rendah porsi kepemilikan institusional suatu perusahaan maka semakin besar pula kemungkinan auditor mengeluarkan opini audit going concern. Maka disusun hipotesis penelitian sebagai berikut:

\section{$\mathrm{H}_{2}$ : Kepemilikan Institusional $\left(X_{2}\right)$ suatu perusahaan mempengaruhi Auditor dalam mengeluarkan opini audit going concern ( $Y$ ).}

Manajer memiliki peranan tersendiri dalam kelangsungan hidup perusahaan, manajer memiliki peranan penting dalam mencapai tujuan perusahaan. Tujuan perusahaan adalah menaikkan nilai perusahaan dengan cara memaksimalkan laba dan memuaskan para pemegang saham. Namun manajer sering menunjukan sikap yang kurang efisien seperti dalam penanganan internal perusahaan maupun menggunakan sumber-sumber perusahaan untuk kepentingan pribadi. Kurangnya efisiensi kinerja manajer dapat mempengaruhi menurunnya nilai perusahaan yang pada akhirnya bila tidak dikoreksi akan menyebabkan kebangkrutan perusahaan. Hal tersebut dapat memperbesar kemungkinan opini audit going concern pada perusahaan.

Jensen dan Meckling (1976) menyatakan kepemilikan manajerial berpengaruh terhadap penurunan biaya perusahaan sehingga dapat menaikkan nilai perusahaan. Hal ini terjadi karena manajer akan merasa memiliki perusahaan sehingga akan meningkatkan efektifitas dan efisiensi manajemen dalam menjalankan dan mengeluarkan kebijakan dalam perusahaan. Hal tersebut dapat meningkatkan nilai perusahaan dan menjauhkan perusahaan dari opini audit going concern.

Berdasarkan teori dan penelitian sebelumnya maka dapat diasumsikan bahwa kepemilikan manajerial mempunyai pengaruh terhadap opini audit going concern, yaitu adanya hubungan negatif antara kepemilikan manajerial dan keluarnya opini going concern.semakin tinggi porsi kepemilikan managerial maka akan memperkecil kemungkinan keluarnya opini audit going concern. Maka disusun hipotesis penelitian sebagai berikut: 


\section{$\mathrm{H}_{3}$ : Kepemilikan Manajerial $\left(\mathbf{X}_{3}\right)$ suatu perusahaan mempengaruhi Auditor dalam mengeluarkan opini audit going concern ( $\mathrm{Y})$.}

\section{METODOLOGI PENELITIAN}

\section{Populasi dan Sampling}

dalam $\begin{array}{rr}\text { Populasi yang } & \text { digunakan } \\ \text { penelitian } & \text { adalah }\end{array}$

perusahaan-perusahaan perbankan teraudit yang tercatat di Bursa Efek Indonesia (BEI) tahun 2005-2010. Sampel dalam penelitian ini diperoleh dengan metode Purposive Sampling dengan minimal 1 tahun memiliki persentase CAR (Capital Adequacy Ratio) < 8\% - 11.9\% dari ATMR (Aktiva Tertimbang Menurut Risiko).

$$
\text { Variabel dependen }
$$

merupakan Opini Audit Going Concern yang merupakan variabel dikotomus. Kategori 1 untuk perusahaan perbankan yang menerima opini audit going concern dan 0 untuk perusahaan perbankan yang tidak menerima opini audit going concern.

Variabel Independen, terdiri dari:

\section{a. Financial Distress}

Diukur dengan menggunakan model prediksi kebangkrutan model modifikasi Altman (1995). Skala yang digunakan adalah skala rasio.
$Z^{\prime \prime}=6,56 \times 1+3,26 \times 2+6,72 \times 3+$ $1,05 \times 4$

Keterangan :

$Z^{\prime \prime}=$ bankrupcy index

$\mathrm{X} 1$ = working capital/total asset

$\mathrm{X} 2$ = retained earnings $/$ total asset

$\mathrm{X} 3=$ earning before interest and taxes/total asset

$\mathrm{X} 4$ = book value of equity/book value of total debt

Indikator $Z^{\prime}$ Score:

$Z^{\prime \prime}<1,1$ bangkrut.

$1,1<Z^{\prime \prime}<2,6$ grey area (tidak

dapat ditentukan apakah perusahaan sehat ataupun mengalami kebangkrutan). $Z^{\prime \prime}>$ 2,6 tidak bangkrut.

\section{b. Kepemilikan Institusional}

Diukur dengan menggunakan total persentase kepemilikan institusional yang ada pada perusahaan yang didapatkan dengan membandingkan jumlah saham yang dimiliki institusi / lembaga dengan jumlah saham beredar. Skala yang digunakan adalah skala rasio dengan menggunakan satuan ukur persen.

Pengukuran : $\frac{\text { Jumlah Saham yang dimiliki institusi/Lembaga }}{\text { Jumlah Saham Beredar }} \times 100 \%$

\section{c. Kepemilikan Manajerial}

Diukur dengan menggunakan total persentase kepemilikan manajerial yang ada pada perusahaan dengan membandingkan jumlah saham yang dimiliki direktur / komisaris 
dengan jumlah saham beredar. Skala yang digunakan adalah skala rasio dengan menggunakan satuan ukur persen.

Pengukuran :

Jumlah Salann yang dimiliki Direktur//Komizaris Jumlah Saham Beredgr?

Data yang digunakan dalam penelitian ini merupakan data sekunder, berupa perusahaan perbankan yang terdaftar di Bursa Efek Indonesia (BEI) dan berupa laporan keuangan (annually report) selama enam tahun yaitu 20052010.

Teknik analisis yang digunakan dalam melakukan pengujian hipotesis dalam penelitian ini adalah analisis regresi logistik. Regresi logistik digunakan untuk memprediksi probabilitas suatu variabel dependen dari sekelompok variabel independen.Variabel dependen yang digunakan pada penelitian ini adalah dichotomus (nominal).

Pembuktian terhadap hipotesis pada penelitian ini menggunakan model regresi logistik dengan 3 variabel bebas sebagai berikut:

$$
L n \frac{p}{1-p}=\alpha+\beta_{1} f d+\beta_{2} \operatorname{Ins}+\beta_{3} \operatorname{Man}+e
$$

Dimana:

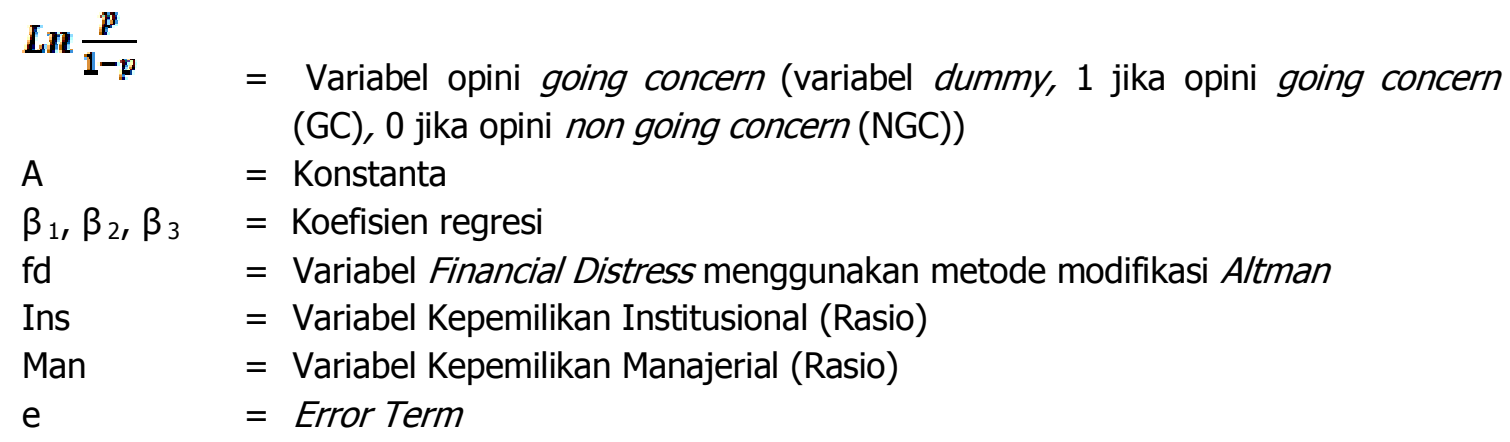

HASIL DAN PEMBAHASAN Statistik deskriptif

Pemilihan sampel menggunakan metode Purposive Sampling dengan perusahaan perbankan minimal 1 tahun memiliki persentase CAR (Capital Adequacy Ratio) $<8 \%-11.9 \%$ dari ATMR (Aktiva Tertimbang Menurut Risiko). Hal ini dilakukan untuk mendeteksi adanya financial distress pada bank yang mempunyai aturan yang 
sangat ketat, dengan ketetapan point ini maka perusahaan dengan angka tersebut mempunyai indikasi masalah keuangan secara tersirat karena mempunyai batasan minim dari standar yang menjadi ketetapan. Sampel yang memenuhi kriteria dapat diolah tampak dalam tabel 1. Penentuan sampel. Sejumlah sampel akhir penelitian selama kurun waktu 2005-2010 menjadi 54 perusahaan perbankan yang terdaftar di BEI. Sebelum membahas nilai yang ada berdasarkan uji statistic deskriptif dan uji hipotesis, maka perlu diingatkan akan komposisi bank yang akhirnya menjadi sampel penelitian ini, secara detail dapat dilihat pada table 4. Kepemilikan saham. Berdasar komposisi pada table 4 terlihat bahwa sebaran angka yang ada tidak merata, sehingga kita harus hati - hati dalam menginterprestasi hasil.

Untuk menjelaskan gambaran umum tentang objek penelitian maka akan dilihat dari hasil uji statistic deskriptif di table.2 descriptive Statistics. Berdasar hasil table 2 , maka untuk variable $\mathrm{Y}$ yaitu munculnya opini audit going concern mempunyai angka mean 0,22 . Hal ini berarti sebagian besar perusahaan yang menjadi sampel adalah perusahaan yang mendapat opini audit non going concern yaitu sebanyak 40 perusahaan dari 54 sampel yang ada. Untuk variable financial Distress menggunakan Altman maka rata rata perusahaan yang menjadi objek penelitian mempunyai nilai Z sebesar 0.251 , berdsar criteria pada model Altman 1995 maka angka ini masuk dalam indicator perusahaan yang bangkrut $\left(Z^{\prime \prime}<1.1\right.$ bangkrut). Angka terendah dipegang oleh bank Mutiara pada tahun 2009 dengan angka -11.41, hal ini berarti berada jauh di bawah 1.1 yang dapat dikategorikan perusahaan berada dalam kondisi yang sangat buruk. Sedangkan angka maximal Z" dipegang oleh bank Victoria International dengan angka 2.13 yang masuk dalam kategori tidak dapat ditentukan apakah perusahaan sehat ataukah sakit (grey area).

Untuk gambaran data dari variable mekanisme GCG, maka variable kepemilikan institusional mempunyai rata-rata sebesar 0.64 artinya sebagian besar dari objek penelitian mempunyai porsi kepemilikan institusional sebesar 64 $\%$. Artinya sebagian besar bank yang jadi objek penelitian mempunyai akses control yang cukup besar dari pihak luar. Sehingga idealnya peranan control mempunyai peluang yang besar untuk dikelola. Angka paling tinggi 
dimiliki bank Mutiara untuk tahun 2009-2010 dengan proporsi pemilikan 100\%, kemudian terendah dimiliki oleh bank Executive . Untuk variable porsi kepemilikan manajerial maka rataratanya adalah 0.101 ini mengindikasikan bahwa bank yang pihak manajemennya mempunyai kepemilikan pada perusahaan hanya $10 \%$ dari total sampel sebesar 54 bank. Perlu dilihat kembali ke table 4. Kepemilikan saham dimana dari komposisi data terlihat bahwa bank yang mempunyai kepemilikan institusional hanya terdapat di beberapa bank saja yaitu bank Bumi Putera, bank Eksekutif dan bank Victoria. Untuk sisanya maka para manajemen tidak punya kepemilikan dari perusahaan.

\section{Uji Hipotesis dan Pembahasan}

Untuk pengujian hipotesis dengan menggunakan uji regesi logit maka berdasarkan hasil tabel 3. Uji hipotesis maka, statistik Wald untuk variabel financial distress adalah sebesar 9,342, sedangkan tingkat signifikansi sebesar 0,002 untuk tingkat signifikan $5 \%$ atau 0,05 . Dapat disimpulkan bahwa Semakin tinggi kondisi Financial distress $\left(X_{1}\right)$ suatu perusahaan, maka semakin kecil kemungkinan Auditor mengeluarkan opini audit going concern (Y). Nilai eksponen financial distress sebesar 0,038 menunjukan bahwa peluang pengaruh financial distress terhadap timbulnya opini audit going concern sebesar 0,038 kali dibandingkan dengan timbulnya opini audit non going concern. Sehingga jika kepemilikan institusional dan kepemilikan manajerial dianggap konstan, maka odds bank akan menyebabkan timbulnya opini audit going concern dengan faktor $\left(\mathrm{e}^{-3,270}\right)$ untuk setiap kenaikan satu unit financial ditress. Financial distress mempunyai nilai eksponen yang paling tinggi dibanding dengan nilai eksponen kepemilikan institusional dan kepemilikan manajerial, hal ini menunjukan bahwa tingginya financial distress mempunyai peluang semakin kecilnya keluar opini audit going concern. Dari hasil analisis olah data konstanta yang negatif $(-3,270)$ dapat disimpulkan bahwa apabila financial distress suatu perusahaan tinggi (memburuk) maka akan memperkecil kemungkinan timbulnya opini audit going concern. Dengan demikian dapat disimpulkan bahwa $\mathrm{H}_{1}$ berhasil didukung. Hasil ini mendukung temuan Setyarno dkk (2006), Santosa dan Wedari (2007), dan Januarti (2009) yang menyatakan bahwa financial distress berpengaruh negatif terhadap timbulnya opini audit going concern. 
Untuk variabel kepemilikan institusional hasil tabel di atas, statistik Wald adalah sebesar 1,803, sedangkan tingkat signifikansi sebesar 0,179 untuk tingkat signifikan $5 \%$ atau 0,05 . Dengan angka hasil uji tingkat signifikansi0,179 diatas 0,05 maka dapat disimpulkan bahwa untuk kepemilikan institusional tidak ditemukan bukti yang kuat adanya hubungan yang menyebabkan keluarnya opini audit going concern. Hal ini dapat dijelaskan dengan mengacu pada deskripsi data penelitian sebelumnya, yaitu tingginya proporsi rata-rata dari data kepemilikan institusional $(64,36 \%)$ yang dimiliki perusahaan perbankan go public di Indonesia. Hal ini artinya Artinya sebagian besar bank yang jadi objek penelitian mempunyai akses control yang cukup besar dari pihak luar. Sehingga idealnya peranan control mempunyai peluang yang besar untuk dikelola, hal ini mengindikasikan bahwa peran control sudah berjalan dengan baik menyebabkan tidak tergambarnya secara jelas pengaruh terhadap timbulnya opini audit going concern. Dominasi yang besar atas saham dan tidak tersebarnya kepemilikan institusional pada perusahaan akan dapat menimbulkan pengaruh yang baik terhadap kondisi perusahaan, dikarenakan akan lebih mengefisienkan aktiva tetap dan modal kerja tahunan perusahaan. Dengan demikian dapat disimpulkan bahwa $\mathrm{H}_{2}$ tidak berhasil didukung. Hasil ini mendukung temuan Januarti (2009) yang menyatakan kepemilikan institusional tidak mempengaruhi terhadap timbulnya opini audit going concern.

Untuk variabel kepemilikan manajerial hasil tabel di atas, statistik Wald adalah sebesar 1,153, sedangkan tingkat signifikansi sebesar 0,283 untuk tingkat signifikan $5 \%$ atau 0,05. Sama seperti variabel kepemilikan institusional, angka signifikansi hasil uji 0,283 yg melebihi 0,05 maka dapat disimpulkan bahwa kepemilikan manajerial tidak berhubungan terhadap timbulnya opini audit going concern. Nilai eksponen kepemilikan manajerial sebesar 0,018 menunjukan bahwa peluang pengaruh kepemilikan manajerial terhadap timbulnya opini audit going concern sebesar 0,018 kali dibandingkan dengan timbulnya opini audit non going concern. Sebenarnya keterkaitan hasil olah data konstanta yang negatif dengan rata-rata data kepemilikan manajerial yang rendah $(10,17 \%)$ harusnya dapat mengahasilkan data yang sesuai dengan hipotesis. Akan tetapi sebaran data dalam table 4 . 
Juga memberi tanda bahwa angka $10 \%$ tersebut hanya merupakan perwakilan dari 3 bank saja atas total keseluruhan sampel penelitian. Maka ketidaksignifikanan variable ini menjadi logis secara factual. Tidak adanya kepemilikan manajemen atas perusahaan dalam industry perbankan memberikan bukti tidak adanya hubungan antara kepemilikan manajerial terhadap timbulnya opini audit going concern. Indikasinya adalah tidak adanya rasa keterikatan pihak pengelola atas kelangsungan hidup perusahaan karena tidak adanya perasaan memiliki perusahaan, memperbesar kemungkinan moral hazard yang bisa dilakukan manajemen. Alasan lain yang dapat diberikan atas terjadinya hal ini juga bahwa keluarnya opini Going Concern bukan dipengaruhi dari rendah dan tingginya proporsi kepemilikan manajerial. Melainkan hal lain yang berhubungan dengan kompetensi dan profesional manajemen dalam menjalankan perusahaan. Dari data yang dimiliki, rata-rata perusahaan perbankan yang memiliki kepemilikan manajerial dimiliki oleh individu yang memiliki keterikatan dalam keluarga. Perusahaan yang manajemennya saling memiliki keterkaitan dalam keluarga dapat menyebabkan kurangnya independensi dalam melakukan kontrol (reward and punishment) terhadap perusahaan karena pihak manajemen yang lain memiliki keterikatan keluarga, kurangnya kompetensi dalam melakukan pekerjaan ganda (sebagai pemilik dan agen yang menjalankan perusahaan) dikarenakan bukan ditangani orang yang tepat pada posisinya, dan kurangnya profesional dalam memberikan kebijakan-kebijakan sektor penting dari perusahaan. Dengan demikian dapat disimpulkan bahwa $\mathrm{H}_{3}$ tidak berhasil didukung. Hasil ini mendukung temuan Januarti (2009) yang menyatakan kepemilikan manajerial tidak mempengaruhi terhadap timbulnya opini audit going concern.

\section{KESIMPULAN DAN SARAN}

Penelitian ini menguji hubungan antara perusahaan financial distress dan mekanisme Good Corporate Governance (GCG) terhadap keluarnya opini audit Going Concern. Berdasarkan pembahasan hasil analisis data yang telah diuraikan, dapat diambil kesimpulan bahwa secara empiris peranan financial distress bank secara statistik ditemukan mempunyai hubungan negative yang signifikan terhadap keluarnya opini audit Going Concern. Dimana 
semakin buruknya financial distress bank maka akan menurunkan kemungkinan keluarnya opini audit Going Concern.

Secara empiris hasil uji statistik dalam penelitian ini tidak mendukung adanya hubungan antara mekanisme Good Corporate Governance (GCG) yang diwakili kepemilikan instusional dan kepemilikan manajerial terhadap keluarnya opini audit Going Concern pada industry perbankan di Indonesia kurun waktu 2005-2010.

Adapun saran untuk penelitian mendatang dapat dilakukan dengan mempertimbangkan hal-hal sebagai berikut:

(1) Tidak dilakukan uji sensitivitas pada hasil uji penelitian ini memberikan batasan dalam menyimpulkan hasil penelitian. Apakah hubungan Financial Distress dan ketidaksignifikanan GCG terhadap keluarnya opini audit Going Concern akan konsisten.

(2) berdasarkan hasil uji penelitian di atas maka akan memberikan insight bagi perusahaan untuk mengembangkan mekanisme internal control dari dalam perusahaan dengan misalnya memberikan porsi kepemilikan perusahaan kepada pihak manajemen (kepemilikan manajerial) agar dapat meminimalisir konflik dan menyatukan tujuan antara pemilik dan manajemen perusahaan. Sehingga faktorfaktor yang dapat mempengaruhi prinsip going concern dapat lebih terkontrol.

(3) Bagi peneliti selanjutnya maka variable kepemilikan konstitusional agar lebih di teliti secara lebih detail dengan melihat pada porsi kepemilikan institusional yang memang mempunyai aksesibilitas untuk melakukan intervensi. Pada penelitian ini hanya menekankan perusahaan yang memiliki proporsi kepemilikan institusionalnya saja ,tanpa merinci apakah institusi-institusi tersebut memang memiliki kepemilikan yang menyebabkan bisa timbulnya akses monitoring internal.

(4) Bagi para pembuat kebijakan untuk dapat melihat indikasi awal pelaksanaan GCG pada sector perbankan sehingga dapat mengembangkan kebijakan dan peraturan yang kondusif untuh menumbuhkan budaya yang sehat pada sector perbankan di Indonesia.

(5) Bagi peneliti berikutnya, diharapkan dapat mengindentifikasi dari sector lain yang dapat menambah 
khasanah

pembahasan

mengenai masalah opini audit Going Concern ataupun mekanisme GCG.

\section{DAFTAR PUSTAKA}

Almilia, Luciana Spica dan Kristijadi. 2003. Analisis Rasio Keuangan Untuk Memprediksi Kondisi Financial Distress Perusahaan Manufaktur Yang Terdaftar di Bursa Efek Jakarta. JAAI Vol. 7 No. 2.

Arens, Alvin A. et al. 2003. Auditing dan Pelayanan Verifikasi : Pendekatan Terpadu. Jakarta: PT Indeks.

Bank Indonesia. 2011. Booklet Perbankan Indonesia. Jakarta: Direktorat Perizinan dan Informasi Perbankan.

Bank Indonesia. 2008. Pedoman Akuntansi Perbankan Indonesia.Jakarta: Direktorat Penelitian dan Pengaturan Perbankan.

Belkaoui, Ahmed Riahi. 2000. Teori Akuntansi. Jakarta: Salemba Empat.

Carcello, J.V., and Neal ,L.T., 2000. Audit Committee composition and auditor reporting, The Accounting Review Vol. 75 no,4; 453-467.

Carmichael,D.R., and K. Pany. 1993. Reporting uncertainties,
Including Going Concern in the expectation GAP Standards: Progress, Implementation Issues, research Oppportunities; 35-58, New York, NY AICPA.

Chow C.W., and S.J. Rice. 1982. Qualified Audit opinion and Auditor Switching. The Accounting Review vol. 57; 326335.

Darmawi, Herman. 2011.Manajemen Perbankan. Jakarta : Bumi Aksara.

Dunil, Z. 2005. Risk-Based Audit : Dalam Pemeriksaan Perkreditan Bank Umum. Jakarta: PT Indeks. Ehrhardt, Michael $\mathrm{C}$ and Eugene F.

Brigham. 2010. Financial

Management : Theory and

Practice. Ohio : Cengage

Learning.

Fabozzi, Frank J. 2009. Finance :

Capital markets, financial

management, and investment

management. New Jersey : John

Wiley \& Sons, Inc.

F. Brigham, Eugene and Joel F.

Houston. 2006. Dasar-dasar

Manajemen Keuangan. Jakarta:

Salemba Empat.

Ghozali, Imam. 2009. Aplikasi analisis Multivariate dengan Program SPSS. Semarang: Badan Penerbit Universitas Diponegoro.

Hidayat, Taufik dan Nina Istiadah. 2011. Panduan Lengkap 
Menguasai SPSS 19 Untuk Mengolah Data Statistik

Penelitian. Jakarta: Mediakita.

Hisrich, Robert D. et al. 2008. Kewirausahaan. Jakarta:

Salemba Empat.

http://www.bbc.co.uk/indonesia/lapo ran_khusus/2010/02/100220_kro nologibankcentury.shtml (diakses tanggal 17 oktober 2011). http://berita.liputan6.com/read/4913 4/bi_dan_bej_membahas_kasus_ bank_lippo (diakses tanggal 17 oktober 2011).

http://www.bi.go.id/web/id/Peratura n/Perbankan/ (diakses tanggal 28 november 2011).

http://idx.co.id/Home/ListedCompani es/ReportDocument/tabid/91/lan guage/en-US/Default.aspx (diakses tanggal 12 februari 2012).

http://www.kompas.com/lipsus0520

09/kotlerread/2008/02/13/09315 078/Kasus. BLBI.sampai.Kapan.A kan.Berakhir. (diakses tanggal 15 Oktober 2011).

Ikatan Akuntan Indonesia. 2009.

Standar Akuntansi Keuangan.

Jakarta: Salemba Empat.

Indonesia Capital Market Directory 2005-2010.

Institut Akuntan Publik Indonesia. 2011. Standar Profesional akuntan Publik. Jakarta: Salemba Empat.
Januarti, Indira . 2009. Analisis

Pengaruh Faktor Perusahaan, Kualitas Auditor, Kepemilikan

Perusahaan Terhadap

Penerimaan Opini Audit Going Concern (Perusahaan Manufaktur Yang Terdaftar di Bursa Efek Indonesia). Simposium Nasional Akuntansi XII.

Jensen, Michael $\mathrm{C}$ and William $\mathrm{H}$. Meckling. 1976. Theory of the Firm: Managerial Behavior, Agency Costs and Ownership Structure. Journal of Financial Economics.

Kasmir. 2011. Manajemen Perbankan. Jakarta : Rajawali Pers.

Lapoliwa, N dan Daniel S. Kuswadi. 2000. Akuntansi Perbankan : Akuntansi Transaksi Bank dalam Valuta Rupiah. Jakarta: Institut Bankir Indonesia.

Levit, A. 1998. Corporate Governance : Integrity in the information age. U.S. Securities \& Ehchange Commisions, at the Corporate Law Institute, New Orlens, LA.

Margaritis, Dimitris and Maria Psillaki. 2008. Capital structure, equity ownership and firm performance. Journal of Banking \& Finance. 
Mulyono, Teguh Pujo. 1999. Bank Auditing : Petunjuk Pemeriksaan Bank. Jakarta: Djambatan.

Ramdhani, Ayu Suci dan Niki Lukviarman. 2009. Perbandingan Analisis Prediksi Kebangkrutan Menggunakan Model Altman Pertama, Altman Revisi, dan Altman Modifikasi dengan Ukuran dan Umur Perusahaan Sebagai Variabel. Jurnal Siasat Bisnis Vol. 13 No. 1.

Riyadi, Selamet. 2006. Banking Assets and Liability Management. Jakarta : Lembaga Penerbit Fakultas Ekonomi Universitas Indonesia.

Santosa, Arga Fajar dan Linda Kusumaning Wedari. 2007. Analisis Faktor-Faktor Yang Mempengaruhi Kecenderungan Penerimaan Opini Audit Going Concern. Jurnal Akuntansi dan Auditing Indonesia, Vol. 11. Salterio, S., and L. Koonce.1997. The Persuasiveness of Audit evidence: the case of accounting policy decisions. Accounting, Organization \& Society, 22 :573857.

Setyarno, Eko Budi. dkk. 2006. Pengaruh kualitas Audit, Kondisi keuangan Perusahaan, Opini Audit Tahun sebelumnya, Pertumbuhan Perusahaan Terhadap opini Audit Going Concern. Simposium Nasional Akuntansi IX.

Supriyono, Maryanto. 2011. Buku Pintar Perbankan. Yogyakarta : ANDI.

Van Horn, James C and John M. Wachowicz, Jr. 2005. Prinsip prinsip Manajemen Keuangan. Jakarta: Salemba Empat.

Van Horn, James C and John M. Wachowicz, Jr. 2007. Prinsip prinsip Manajemen Keuangan. Jakarta: Salemba Empat. Warren, Carl S. et al. 2008. Pengantar Akuntansi. Jakarta : Salemba Empat. 